\title{
TILLING is an effective reverse genetics technique for Caenorhabditis elegans
}

\author{
Erin J Gilchrist*1, Nigel J O'Neil2, Ann M Rose ${ }^{2}$, Monique C Zetka ${ }^{3}$ and \\ George W Haughn ${ }^{1}$
}

Address: ${ }^{1}$ Department of Botany, 6270 University Blvd, University of British Columbia, Vancouver, BC, V6T 1Z4, Canada, ${ }^{2}$ Department of Medical Genetics, University of British Columbia, Vancouver, BC, V6T 1Z3, Canada and 32Department of Biology, McGill University, Stewart Building N5/ 16, 1205 Avenue Docteur Penfield, Montreal, QC, H3A 1B1, Canada

Email: Erin J Gilchrist* - ering@interchange.ubc.ca; Nigel J O'Neil - noneil@gene.nce.ubc.ca; Ann M Rose - arose@gene.nce.ubc.ca; Monique C Zetka - monique.zetka@mcgill.ca; George W Haughn - haughn@interchange.ubc.ca

* Corresponding author

Published: 18 October 2006

BMC Genomics 2006, 7:262 doi:10.1/86/147|-2/64-7-262
Received: 12 May 2006

Accepted: 18 October 2006

This article is available from: http://www.biomedcentral.com/I47I-2I64/7/262

(C) 2006 Gilchrist et al; licensee BioMed Central Ltd.

This is an Open Access article distributed under the terms of the Creative Commons Attribution License (http://creativecommons.org/licenses/by/2.0), which permits unrestricted use, distribution, and reproduction in any medium, provided the original work is properly cited.

\begin{abstract}
Background: TILLING (Targeting Induced Local Lesions in Genomes) is a reverse genetic technique based on the use of a mismatch-specific enzyme that identifies mutations in a target gene through heteroduplex analysis. We tested this technique in Caenorhabditis elegans, a model organism in which genomics tools have been well developed, but limitations in reverse genetics have restricted the number of heritable mutations that have been identified.

Results: To determine whether TILLING represents an effective reverse genetic strategy for $C$. elegans we generated an EMS-mutagenised population of approximately 1500 individuals and screened for mutations in 10 genes. A total of 71 mutations were identified by TILLING, providing multiple mutant alleles for every gene tested. Some of the mutations identified are predicted to be silent, either because they are in non-coding DNA or because they affect the third bp of a codon which does not change the amino acid encoded by that codon. However, $59 \%$ of the mutations identified are missense alleles resulting in a change in one of the amino acids in the protein product of the gene, and $3 \%$ are putative null alleles which are predicted to eliminate gene function. We compared the types of mutation identified by TILLING with those previously reported from forward EMS screens and found that $96 \%$ of TILLING mutations were G/C-to-A/T transitions, a rate significantly higher than that found in forward genetic screens where transversions and deletions were also observed. The mutation rate we achieved was $1 / 293 \mathrm{~kb}$, which is comparable to the mutation rate observed for TILLING in other organisms.
\end{abstract}

Conclusion: We conclude that TILLING is an effective and cost-efficient reverse genetics tool in $C$. elegans. It complements other reverse genetic techniques in this organism, can provide an allelic series of mutations for any locus and does not appear to have any bias in terms of gene size or location. For eight of the 10 target genes screened, TILLING has provided the first genetically heritable mutations which can be used to study their functions in vivo. 


\section{Background}

Caenorhabditis elegans is a well-established model system (reviewed by Hodgkin [1]) that is increasingly being used for genetic and molecular investigations into conserved biological processes, including those involved in human disease [2-5]. Although simple in structure, C. elegans is comparable to higher animals in development and forms most of the major tissue types that are important to vertebrate physiology. Indeed, in a comparison of 18,452 C. elegans protein sequences against human EST databases, $83 \%$ (15,344 sequences) of the C. elegans sequences were found to have human homologues [6].

Because the sequence of the complete C. elegans genome has been available since 1998, bioinformaticians have been presented with ample opportunity to mine the data, and a plethora of genomic and proteomic information is accessible to researchers wishing to build upon this information [7]. Powerful in silico techniques have also been developed for the analysis of genome sequence information and are used in the prediction of gene function, expression and interaction [5,8,9]. Despite the exciting possibilities flowing from these studies, the testing of predictions made in silico relies largely on the existence of efficient reverse genetic approaches that target specific genes or classes of genes in vivo. In vitro techniques such as yeast two-hybrid analysis [10] and microarray analysis [11] have also been used to generate an abundance of valuable data about gene expression and protein interactions but, like the data generated in silico, these data need to be verified in vivo.

C. elegans has approximately 19,800 protein-coding genes and 12,000 of these have been conserved over the 100 million years since this species has diverged from the related nematode Caenorhabditis briggsae, indicating that they are likely important functional genes [12]. In spite of this fact, however, only about 3,400 genes in C. elegans have mutant alleles available for genetic and biochemical analysis to ascertain their function and importance [13]. High-throughput reverse genetics is an ideal way of generating mutations in the remaining 16,400 genes and several such approaches have been developed for the nematode each of which has advantages and drawbacks that affect the applicability or efficiency of the technique as a tool for probing gene function on a genomic scale.

Currently, the most efficient and popular method to disrupt the activity of a gene in C. elegans is the technique of RNA interference (RNAi) [14]. Large-scale RNAi screens have demonstrated that the function of a diverse population of genes with roles in many biological processes can be disrupted by the injection of double-stranded RNA (dsRNA) directly into the gonad [15], by soaking the nematodes in a dsRNA solution [16], or by feeding the nema- todes bacteria expressing dsRNA $[17,18]$. These same studies, however, have also documented that the phenotypes resulting from the RNAi treatment often depend on the method of delivery. In addition, the RNAi technique cannot replace classical genetic analysis because the phenotypic effects are transient and not heritable, making classical genetic interaction studies impossible.

Another effective reverse-genetic technique that is being used successfully in C. elegans is mutagenesis with trimethylpsoralen and ultraviolet radiation (TMP/UV) followed by detection of gene knockouts by PCR. This is currently the method of choice for obtaining heritable loss-of-function mutations in C. elegans but there are also drawbacks to this approach. First, the limitations of the detection method necessitate using a high dosage of mutagen which requires multiple rounds of outcrossing to remove accompanying background mutations. In addition, missense alleles cannot be isolated and large deletion events may result in the loss of function from more than one locus simultaneously. Finally, although the reason for this is unclear, mutations in certain genes have been more difficult to obtain than in others.

Transposon-insertion mutagenesis is another tool that is available to the C. elegans community $[19,20]$ but it shares many of the limitations discussed for the previous techniques in addition to some that are specific to this approach such as the fact that small genes are less likely to be targets of transposon insertion and certain regions of the genome may vary in the frequency at which transposons insert. The mutagenic effect of Tc1 insertions can also sometimes be circumvented by innate compensation mechanisms that allow spicing around the transposon.

A recently reported study of biolistic transformation in $C$. elegans indicates that homologous recombination of introduced DNA is also possible in this species [21] but, in spite of the potential of this technique to provide the long-sought ability to perform site-directed mutagenesis in C. elegans, the low success rate and the fact that an elaborate microparticle bombardment set-up is required, make it unlikely that this procedure will soon become efficient enough for high-throughput reverse genetics.

As a result of drawbacks in currently used reverse genetic techniques, the pace of research into biological processes in C. elegans is still largely dictated by the probability of obtaining a mutant of any given gene and, thus, new techniques are needed to complement those previously described. TILLING (Targeting Induced Local Lesions in Genomes) is a relatively novel reverse genetics technique based on the use of a mismatch-specific enzyme that will identify mutations in any target gene through heteroduplex analysis [22]. The technique involves PCR amplifica- 
tion of a target gene or region of DNA using fluorescently labelled primers, followed by digestion with an enzyme that specifically cleaves at the site of a mismatch such as that induced by ethylmethanesulfonate (EMS) mutagenesis (see Figure 1). The sizes of the cleavage fragments resolved on polyacrylamide gels reveal the approximate position of the mutation within the amplicon. We report here on a pilot project to test the use of this technology in C. elegans: we have constructed and arrayed a mutagenised population and used it to isolate mutations in 10 different genes. On the basis of these data we conclude that TILLING is as effective and cost-efficient in C. elegans as it has been shown to be in other species in which it has been tested [23-29].

\section{Results and Discussion Efficiency of TILLING in C. elegans}

To determine whether TILLING represents an effective reverse genetic strategy for $C$. elegans we generated and arrayed an EMS-mutagenised population of approximately 1500 individual animals (see below) and screened for mutations in 10 genes varying in size from 788 base pairs (bp) to $9112 \mathrm{bp}$. A region of approximately $1500 \mathrm{bp}$ from each gene was examined and a total of 71 novel mutations were identified by TILLING, thus providing multiple mutant alleles for each gene (Table 1). Some of the mutations we identified are predicted to be silent, either because they are in non-coding DNA or because they affect the third bp of a codon which does not change the amino acid encoded by that codon. However, $59 \%$ of the mutations we identified are missense alleles resulting in a change in one of the amino acids in the protein product of the gene, and 3\% are nonsense alleles resulting from the insertion of a premature stop codon into the coding region of the gene, or in the elimination of a conserved splice junction site. These data demonstrate the efficacy of TILLING in C. elegans.

\section{Comparison of forward and reverse genetics with EMS mutagenesis}

A C. elegans population was constructed for this TILLING project using the mutagen EMS (Figure 2). EMS was chosen because it has been shown to be an effective mutagen in this species and because it is known to generate primarily single bp mutations which can be identified using TILLING [23,30-34].

A survey of Wormbase [7] was performed in order to examine the type of molecular lesion induced by EMS in C. elegans to ensure that the majority of these mutations are, indeed, small intergenic lesions of the type that can be identified by TILLING (see Additional File 1 for a list of alleles). Two hundred and thirteen alleles from 51 different genes whose molecular sequence was known were selected randomly from the database. All of the mutations were reported to be identified in screens of EMS-treated animals. Ninety three percent of the 213 alleles examined from Wormbase were found to be single bp mutations. Eighty seven percent were G/C-to-A/T transitions, six percent were other single bp mutations, and seven percent of the mutations reported were deletions that ranged in size from $88 \mathrm{bp}$ to $2.3 \mathrm{~kb}$.

In our TILLING experiment, 68 of the 71 independent mutations identified (96\%) were G/C-to-A/T transitions and the remaining three mutations were $\mathrm{A} / \mathrm{T}$-to- $\mathrm{T} / \mathrm{A}$ or $\mathrm{G} /$

Table I: List of TILLING targets, sizes of amplicons and number and type of mutations identified for each gene.

\begin{tabular}{|c|c|c|c|c|c|c|c|c|c|}
\hline Gene Name & Description & $\begin{array}{r}\text { Gene } \\
\text { Size (bp) }\end{array}$ & $\begin{array}{r}\text { PCR } \\
\text { Size (bp) }\end{array}$ & $\begin{array}{l}\text { I'Prev. } \\
\text { alleles }\end{array}$ & $\begin{array}{l}\text { 2Prev. } \\
\text { strains }\end{array}$ & $\begin{array}{l}\text { 3Mis- } \\
\text { sense }\end{array}$ & ${ }^{3}$ Null & 3 Silent & ${ }^{3}$ Total \\
\hline$* \mathrm{C} 05 \mathrm{Cl} 0.5$ & Hypothetical protein & 788 & 1175 & 0 & 0 & 2 & & I & 3 \\
\hline mel-32 C05DII.II & Serine hydroxyl-methyl-transferase & 1600 & 1500 & 16 & I & 4 & 1 & 2 & 7 \\
\hline mus-8I C43EII.2 & Endonuclease MUS8I & 2530 & $117 \mid$ & 1 & 0 & 4 & & 3 & 7 \\
\hline xpf-I C47DI2.8 & Structure-specific endonuclease ERCCI-XPF & 9112 & 1452 & 0 & 0 & 5 & & 3 & 8 \\
\hline$* F 25 \mathrm{H} 2.13$ & Helicase of the DEAD superfamily & 4985 & 1499 & I & 0 & 5 & & 4 & 9 \\
\hline$h t p-3$ F57C9.5 & HIM-3 paralogue & 2598 & 1452 & I & I & 5 & & 5 & 10 \\
\hline$* \mathrm{M} 03 \mathrm{CII} .2$ & Helicase of the DEAD superfamily & 5943 & 1490 & I & 0 & 4 & & 1 & 5 \\
\hline cki-2 T05A6.2 & Hypothetical protein & 1555 & 1569 & 0 & 0 & 7 & 1 & 2 & 10 \\
\hline$m d f-2$ Y69A2AR.30 & Spindle assembly checkpoint protein & 4461 & 1466 & 1 & 0 & I & & 5 & 6 \\
\hline$h t p-2$ Y73B6BL.2 & HIM-3 paralogue protein 2 & 1199 & $|45|$ & 0 & 0 & 5 & & I & 6 \\
\hline Totals & & & 14225 & & & 42 & 2 & 27 & 71 \\
\hline
\end{tabular}

* Gene name not assigned

I Number of mutant alleles listed in Wormbase [7] as existing prior to this study.

2 Number of mutant strains available from the Caenorhabditis Genetic Stock Center.

${ }^{3}$ Number of mutations of this type identified in this TILLING study.

Missense mutations alter the amino acid sequence of the encoded protein. Null mutations refer to mutations that convert an amino acid codon into a premature stop codon, or that alter a conserved splice junction and result in premature truncation of the protein product of the gene. Silent mutations are changes that do not affect the protein product of the gene. These include mutations in introns or intergenic sequences, and mutations that alter the third bp of a codon in such a way that it does not change the amino acid encoded by that codon. 


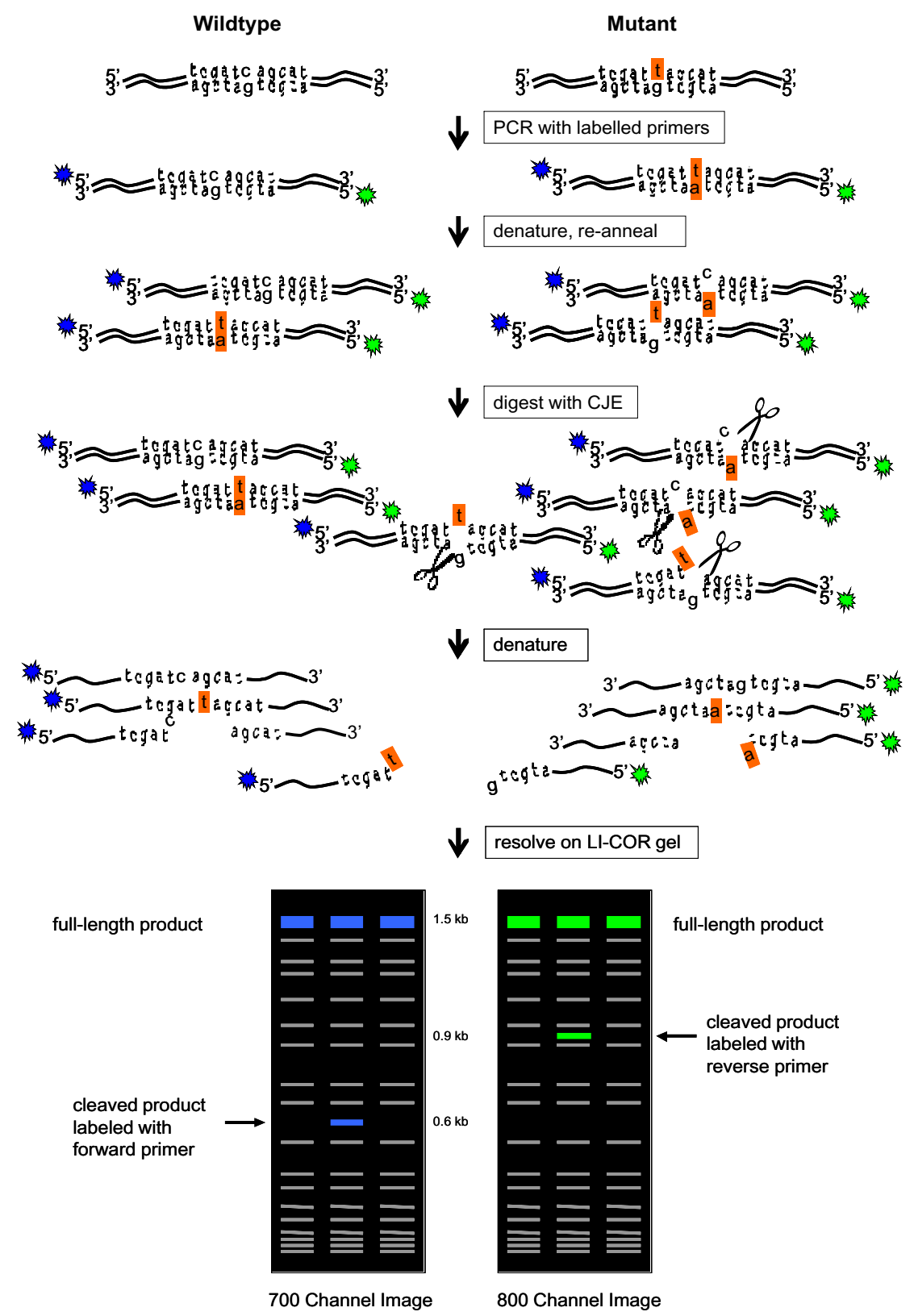

\section{Figure I}

Overview of the TILLING procedure. Pooled DNA is amplified using fluorescently tagged, gene-specific primers. The forward and reverse primers are labelled with different fluorophors that label both ends of the fragment. The amplified products are denatured by heating and then allowed to cool slowly so that they randomly re-anneal. Heteroduplex molecules form when mutant and wild-type PCR products anneal together, and these then become targets for a single-strand-specific nuclease found in Celery Juice Extract (CJE). The nuclease cleaves these heteroduplex fragments at one of the two strands, 3 ' to the site of the mismatch in the DNA. The PCR products that retain one of the labelled primers can then be detected on polyacrylamide denaturing LI-COR gels. Individuals with a mutation in the gene of interest are identified by the smaller cleavage fragment seen on the gel as well as the wild-type product. Because the nuclease cleaves either of the two strands randomly, cleavage products can be detected in both the IRD700 and IRD800 channels of the gel image. The position of the mutation within the PCR amplicon can be calculated from the size of the two fragments carrying the forward, IRD700-labeled primer, and the reverse, IRD800-labeled primer. Grey bands on the gel are thought to result from partial PCR products and aid in sizing of mutant bands. 


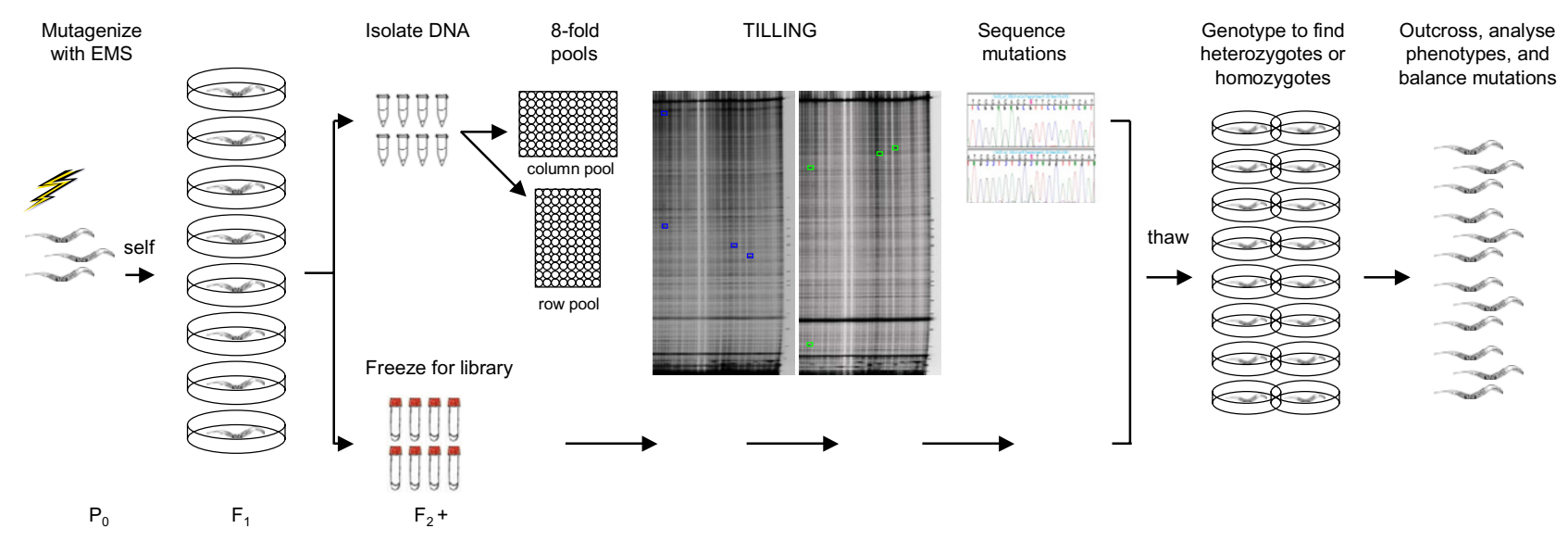

\section{Figure 2}

Outline of $C$. elegans TILLING procedure. Animals are mutagenised with EMS, picked individually to plates, and allowed to self. One third of the worms are used for DNA and the remaining two thirds are frozen for future analysis. DNA is pooled 8-fold to reduce time and expense. TILLING is performed in order to determine which individuals carry mutations in the gene of interest. Mutations are sequenced and individuals from lines carrying mutations that have an effect on the gene product are thawed and genotyped to isolate heterozygous or homozygous mutants.

C-to-T/A transversions (Table 2). This percentage of G/Cto-A/T transitions is significantly higher than that found in forward genetic screens and probably reflects the fact that many EMS-induced lesions are not identified using classical genetic screens because they do not have an effect on phenotype. The frequency of transversions seen with TILLING in our screen is similar to the frequency found in forward genetic screens using EMS in C. elegans (6\%), but significantly lower than the number of transversions mutations reported in a small Drosophila TILLING project (16\%) [29], and significantly higher than the number found in Arabidopsis where greater than 99\% of mutations sequenced were G/C-to-A/T transitions [23].

Three of the mutant strains we generated in this study, CN579, CN1162 and CN1574 carried two point mutations within the target gene. In each case, one of the second-site mutations was in non-coding DNA and so presumably would not affect the phenotype of the animals carrying the linked mutation. Second-site mutations have been reported in forward genetic screens of EMStreated worms as well. A case in point is the molecular analysis of unc-52 mutations and intragenic suppressor alleles [35]. Two of the 19 mutations sequenced in the unc-52 study carried a second site mutation less than 400 bp upstream of the primary mutation. One of these second-site mutations was a single bp transition, and the other was a $311 \mathrm{bp}$ deletion. In both cases, the second-site mutations were not found to affect the phenotype of the animals carrying them. Second-site mutations have also been found in EMS screens of yeast [33] and Drosophila
[34], and so presumably reflect some common DNA repair mechanism that is induced upon EMS damage.

Deletions are another type of mutation that has been reported in forward genetic screens using EMS in several different species $[30,32,34]$. In C. elegans approximately $7 \%$ of all mutations from forward genetic screens of EMStreated animals are deletions (Additional File 1). We did not identify any deletions in this TILLING project but we are confident (based on previous studies $[23,36]$ ) that if EMS does generate this type of mutation in C. elegans, TILLING will be able to detect these events as well as the single base pair changes that are more common. The reason that deletions have been identified more frequently in forward genetic screens than in our reverse genetic screen is probably because these mutations are much more likely to produce a phenotype than the single bp mutations more commonly produced by EMS.

\section{Mutagen dose and mutation rate}

The dose of EMS used for our TILLING project $(0.025 \mathrm{M})$ was lower than that used in many forward genetic screens because studies have shown that this lower dose simplifies the identification of mutant phenotypes caused by the gene of interest while limiting confounding background phenotypes or lethality [37]. In two strains, however (CN843 and CN1643), we identified mutations in two different genes in the same strain. While this might seem to indicate a very high overall mutation frequency, we do not believe that this is the case since the mutagenised animals seem healthy and fertile, and since the overall muta- 
Table 2: Mutations identified by TILLING.

\begin{tabular}{|c|c|c|c|c|}
\hline Gene & Strain & Allele & Change & Effect \\
\hline $\mathrm{C} 05 \mathrm{Cl} 10.5$ & CN556 & vc2l & $\mathrm{CII} 2 \mathrm{~T}$ & P23S \\
\hline $\mathrm{C} 05 \mathrm{Cl} 0.5$ & CNI 688 & vc40 & GI78A & G45R \\
\hline $\mathrm{C} 05 \mathrm{Cl} 0.5$ & CNI746 & vc4l & G230A & Non-coding \\
\hline mel-32 C05DII.II & CN843 & $\mathrm{vcll}$ & G36IA & V106I \\
\hline mel-32 C05DII.II & CNII8I & vc68 & $\mathrm{Cl} 339 \mathrm{~T}$ & Q416* \\
\hline mel-32 C05DII.II & CNI62I & vc69 & G289A & G82R \\
\hline mel-32 C05DII.II & CNI665 & vc70 & G373A & DIION \\
\hline mel-32 C05DII.II & CNI738 & vc7l & G384A & $\mathrm{K} I \mathrm{I}=$ \\
\hline mel-32 C05DI I.II & CNI805 & vc72 & G972A & $K 293=$ \\
\hline mel-32 C05DII.II & CNI856 & vc73 & G373A & DIION \\
\hline mus-8I C43EII.2 & CNII62 & vc42 & Cl830T & L368F \\
\hline mus-8I C43EII.2 & CNII 62 & vc43 & GI23IA & Non-coding \\
\hline mus-8I C43EII.2 & $C N I 2 I I$ & vc44 & A955T & Non-coding \\
\hline mus-8I C43EII.2 & CNI456 & vc45 & G972A & Non-coding \\
\hline mus-8I C43EII.2 & CNI604 & vc46 & GI897A & G390E \\
\hline mus-8I C43EII.2 & CNI766 & vc47 & CI687T & T320I \\
\hline mus-8I C43EII.2 & CN568 & vc48 & GI3I3A & $\mathrm{D} 214 \mathrm{~N}$ \\
\hline xpf-I C47DI2.8 & CN665 & $\mathrm{vcl} 8$ & $\mathrm{C} 602 \mathrm{~T}$ & LI83F \\
\hline xpf-I C47DI 2.8 & CN720 & $\mathrm{vcl9}$ & G930A & $\mathrm{R} 292 \mathrm{H}$ \\
\hline xpf-I C47DI 2.8 & CNI286 & vc62 & GI036A & R278Q \\
\hline xpf-I C47DI 2.8 & CNI475 & vc63 & G446A & EIOOK \\
\hline xpf-I C47DI 2.8 & CNI574 & vc64 & CIOIT & Non-coding \\
\hline xpf-I C47DI2.8 & CNI574 & vc65 & G8।8T & S205= \\
\hline xpf-I C47DI 2.8 & CNI75I & vc66 & C902T & V233= \\
\hline xpf-I C47DI 2.8 & CNI798 & vc67 & G942A & $\mathrm{D} 247 \mathrm{~N}$ \\
\hline $\mathrm{F} 25 \mathrm{H} 2.13$ & CN838 & $\mathrm{vcl0}$ & Al200T & $1277 \mathrm{~F}$ \\
\hline $\mathrm{F} 25 \mathrm{H} 2.13$ & CNI245 & vc52 & GI206A & E279K \\
\hline $\mathrm{F} 25 \mathrm{H} 2.13$ & CNI326 & vc53 & G42IA & Non-coding \\
\hline $\mathrm{F} 25 \mathrm{H} 2.13$ & CNI742 & vc54 & G285A & $E 95=$ \\
\hline $\mathrm{F} 25 \mathrm{H} 2.13$ & $\mathrm{CN} 1812$ & vc55 & G399A & Non-coding \\
\hline $\mathrm{F} 25 \mathrm{H} 2.13$ & CNI838 & vc56 & GII67A & $\mathrm{A} 266 \mathrm{~T}$ \\
\hline $\mathrm{F} 25 \mathrm{H} 2.13$ & CN579 & vc7 & C649T & Non-coding \\
\hline $\mathrm{F} 25 \mathrm{H} 2.13$ & CN579 & vc8 & $\mathrm{Cl} 165 \mathrm{~T}$ & S265F \\
\hline $\mathrm{F} 25 \mathrm{H} 2.13$ & CN48 & vc9 & GI242A & E29IK \\
\hline$h t p-3$ F57C9.5 & CN646 & $\mathrm{vcl}$ & G2224A & E616K \\
\hline$h t p-3$ F57C9.5 & CN823 & $\mathrm{vcl3}$ & GI785A & $E 469=$ \\
\hline htp-3 F57C9.5 & CN727 & $\mathrm{vc2}$ & G2029A & E55IK \\
\hline htp-3 F57C9.5 & CNI362 & vc23 & $\mathrm{C} 2048 \mathrm{~T}$ & P557L \\
\hline htp-3 F57C9.5 & CNI369 & vc24 & G1905A & S509= \\
\hline htp-3 F57C9.5 & CNI425 & vc25 & G2I8IA & Q60I= \\
\hline$h t p-3$ F57C9.5 & CNI 630 & vc26 & G2230A & V6181 \\
\hline htp-3 F57C9.5 & CNI723 & vc27 & CI245T & P306L \\
\hline$h t p-3$ F57C9.5 & CNI735 & vc28 & C233IT & $Y 65 I=$ \\
\hline$h t p-3$ F57C9.5 & CN825 & vc3 & GI333A & R335= \\
\hline M03CII.2 & CNI246 & vc57 & G4804A & E680K \\
\hline $\mathrm{M03ClI.2}$ & CNI479 & vc58 & G5097A & G725D \\
\hline $\mathrm{M03ClI.2}$ & CNI543 & vc59 & C4755T & $1663=$ \\
\hline $\mathrm{M} 03 \mathrm{Cl} I .2$ & CNI643 & vc60 & C4739T & P658L \\
\hline $\mathrm{M} 03 \mathrm{Cl} \mathrm{I} .2$ & CNI7I2 & vc6I & C5740T & $\mathrm{H} 782 \mathrm{Y}$ \\
\hline$C_{k i-2}$ T05A6.2 & CN843 & vc20 & $\mathrm{C} 413 \mathrm{~T}$ & $\mathrm{TI} 23 \mid$ \\
\hline Cki-2 T05A6.2 & CNIII57 & vc3l & G869A & Non-coding \\
\hline Cki-2 T05A6.2 & CNI23I & vc32 & C338T & T98I \\
\hline Cki-2 T05A6.2 & CNI254 & vc33 & G2I4A & G57R \\
\hline Cki-2 T05A6.2 & CNI309 & vc34 & G524A & EI46K \\
\hline$C_{k i-2}$ T05A6.2 & CNI364 & vc35 & G876A & Non-coding \\
\hline Cki-2 T05A6.2 & CNI575 & vc36 & G370A & VI09M \\
\hline$C_{k i-2}$ T05A6.2 & CNI643 & vc37 & CI70T & $\mathrm{S} 42 \mathrm{~F}$ \\
\hline Cki-2 T05A6.2 & CNI672 & vc38 & GI48A & E35K \\
\hline Cki-2 T05A6.2 & CNI787 & vc39 & G76A & Splice Junction \\
\hline
\end{tabular}


Table 2: Mutations identified by TILLING. (Continued)

\begin{tabular}{|c|c|c|c|c|}
\hline$m d f-2$ Y69A2AR.30 & CN7II & $\mathrm{vcl5}$ & G243A & $\mathrm{D} 65 \mathrm{~N}$ \\
\hline$m d f-2$ Y69A2AR.30 & CN902 & vcl7 & Cl083T & Non-coding \\
\hline$m d f-2$ Y69A2AR.30 & CNI6I3 & vc49 & C838T & Non-coding \\
\hline$m d f-2$ Y69A2AR.30 & CNI703 & vc50 & C838T & Non-coding \\
\hline$m d f-2$ Y69A2AR.30 & CNI865 & vc5I & C520T & Non-coding \\
\hline$m d f-2$ Y69A2AR.30 & CNIII4 & vc74 & G76A & Non-coding \\
\hline$h t p-2$ Y73B6BL.2 & CN750 & $\mathrm{vcl} 4$ & C507T & $\mathrm{Al} 39 \mathrm{~V}$ \\
\hline$h t p-2$ Y73B6BL.2 & CN50 & vc22 & C756T & $\mathrm{T} 222 \mathrm{I}$ \\
\hline$h t p-2$ Y73B6BL.2 & CNI27I & vc29 & C7II2T & S207= \\
\hline$h t p-2$ Y73B6BL.2 & CNI540 & vc30 & G345A & $\mathrm{R} 85 \mathrm{Q}$ \\
\hline htp-2 Y73B6BL.2 & CN574 & vc5 & G49A & DI7N \\
\hline$h t p-2$ Y73B6BL.2 & CN90I & vc6 & G878A & G263R \\
\hline
\end{tabular}

One letter nucleotide and amino acid codes follow IUPAC-IUB nomenclature. The first letter in the Nucleotide Change column indicates the wildtype nucleotide at this site, followed by the position of the mutation from the start codon in the genomic DNA and then the mutant nucleotide. The first letter in the Effect column indicates the wildtype amino acid at this site, followed by the position of the mutation within the predicted protein sequence and then mutated amino acid. An equal sign after the amino acid position means no change in the amino acid encoded by that codon, and an asterisk indicates a stop codon. Mutations in introns and intergenic regions are designated "Non-coding".

tion rate was calculated to be one mutation every $293 \mathrm{~kb}$ (71 mutations in 14225 bp of DNA from 1464 animals). This is not significantly higher than the rate of one mutation in $300 \mathrm{~kb}$ seen for TILLING in Arabidopsis [23], and is lower than the rate of one mutation in $156 \mathrm{~kb}$ reported for Drosophila [29]. Hence, the 0.025M dose of EMS appears to be an adequate dose for TILLING based on comparison with these other systems in which this technique is currently being used.

\section{Effects of mutations identified through TILLING}

The spectrum of mutations identified through forward and reverse screens using EMS, although similar at the level of DNA sequence is much different when the effects of the mutations are compared. Of the 194 single bp mutations we analysed from Wormbase (Additional File 1) $50 \%$ resulted in missense alleles and the remaining $50 \%$ in nonsense or splice junction mutations. In our TILLING screen, because the selection of mutants was not based on phenotype, $38 \%$ of the mutations we identified are predicted to be silent. These include mutations in introns and intergenic regions and mutations that alter the third bp of a codon such that it still encodes the wildtype amino acid. The majority of the mutations we identified (59\%) were missense alleles that alter the amino acid sequence of the protein encoded by the target gene (Table 2). Of the 42 missense mutations identified in our screen, 17 of these may not have a significant effect on phenotype since the amino acid mutated was replaced by an amino acid of similar charge and polarity, but the 25 remaining missense mutations are predicted to significantly affect the structure of the protein product of the target gene by changing the charge or hydrophobicity of this region of the protein.

Two of the mutations identified in our TILLING screen, mel-32 C05D11.11(vc68) and cki-2 T05A6.2(vc39), are predicted to result in a complete loss-of-function, or null, phenotype because they truncate the protein product of the gene. One of these introduces a premature stop codon into the third exon of gene mel-32 C05D11.11, and the other is a splice junction mutation that eliminates the splice donor site of first intron of the gene cki-2 T05A6.2 (Figure 3). The proportion of putative null mutations identified in our screen was $3 \%$ which is not significantly different than the frequency of $2 \%$ seen in the Drosophila TILLING study published [29] or than the 5\% reported from the much larger Arabidopsis TILLNG project [23]. This frequency is higher than would be expected using other chemical mutagens in C. elegans such as ENU [38] which cause a different spectrum of mutagenic events that are more likely to result in missense than nonsense mutations.

\section{Pooling and library construction}

A frozen library of approximately 1500 individual EMStreated lines of $C$. elegans was constructed for this study (Figure 2), and DNA was isolated, purified, and arrayed in pools of eight as has been shown to work for TILLING in other diploid species such as Arabidopsis thaliana [22], Lotus japonicas [24], Zea maize [27] and Brassica oleracea [Gilchrist and Haughn, unpublished]. Purification of the DNA was found to be necessary both because the TILLING reactions did not work on unpurified DNA samples and because accurate quantitation of the samples is essential before pooling so that DNA from mutant animals is sufficiently represented in the 8-fold pools [27]. Both 4-fold and 12 -fold pools were tested in C. elegans in order to confirm that 8 -fold pooling would be efficient (see Materials and Methods for details). With 4-fold pooling all of the mutant bands were detected, as they were with the 8-fold pools, whereas with 12 -fold pooling only a subset of the mutant bands were seen on the TILLING gel. Although 10fold pools might be possible in $C$. elegans given that the genome size of this organism is slightly smaller than Arabidopsis, the construction of libraries for screening in 96 or 


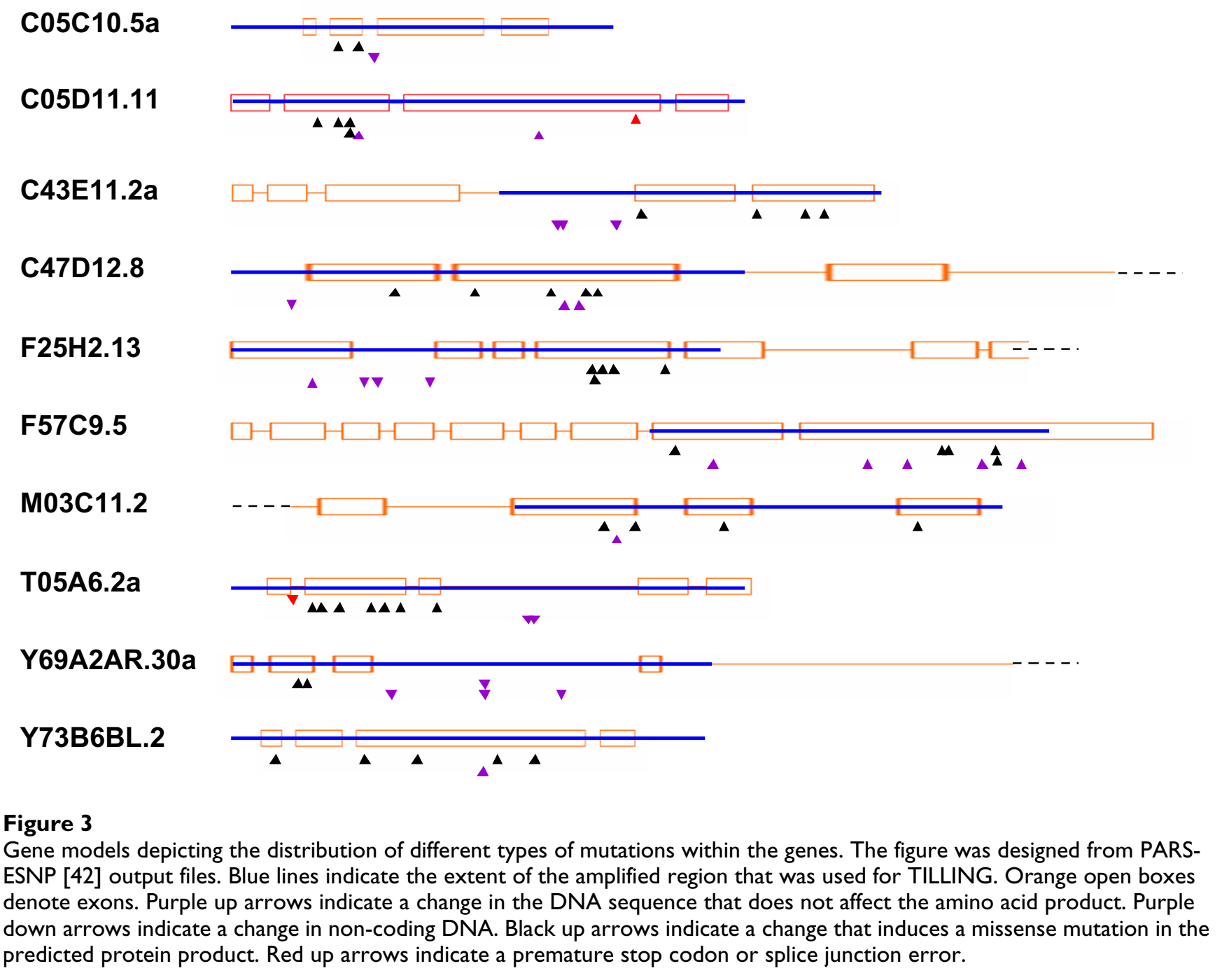

384-well plates dictates that pooling is only efficient in multiples of eight or 12 , and since mutations are missed with 12-fold pooling in C. elegans, libraries constructed for this TILLING study were pooled in 8-fold aliquots.

Our first library consisted of 696 rather than the planned $768(8 \times 96)$ mutagenised worms because the DNA quality in 72 of the 768 lines established was too poor to be used for TILLING. Only 8-fold column pools were constructed for this library and when a mutation was detected in a column pool well, each of the eight individuals that made up that pool was examined by TILLING in order to determine which strain carried the mutation. For the second library of 768 animals, however, both 8-fold row pools and 8-fold column pools were constructed and screened. The DNA from individual worms was arrayed in 12 , eight-by-eight grids so as to simplify pooling in either direction. Then the DNA was pooled by combining sam- ples from one row or one column into a single pool, resulting in a total of 96 pools. The identity of the strain carrying a mutation detected on the TILLING gels was computed automatically by cross-referencing the data from the row and column pools.

In theory, the method used for screening library \# 1 only required an average of 120 reactions: one 8-fold column pool, plus eight individuals for each of three mutations detected ( 24 additional reactions). However, the 24 reactions done to determine which individual from a pool carried the mutation had to be set up manually and often needed to be repeated in order to ensure that all of the reactions worked. Thus, this pooling strategy was more time-consuming and often required almost as many TILLING reactions as the screening of both row and column pools simultaneously. In addition, the row and column pool strategy allowed false positive bands to be excluded 
Table 3: Primers used to amplify target genes in pilot $C$. elegans TILLING project

\begin{tabular}{|c|c|c|}
\hline Gene & Oligo Name & Oligo Sequence \\
\hline \multirow[t]{2}{*}{ F57C9.5 } & ce000ILb & GTGCTGAGAATCCTGAACTTGACG \\
\hline & ce000IR & TCTACTTGGCATGTTCGGCGACTG \\
\hline \multirow[t]{2}{*}{ Y73B6BL.2 } & ce0002L & GGGTTCGCGAATTTCACTTGCATT \\
\hline & ce0002R & CGGCTCCTCTGCGAGTAGTTGGTC \\
\hline \multirow[t]{2}{*}{ T05A6.2 } & ce0003L & GCGGCGCACTCACATTTTTCTCTT \\
\hline & ce0003R & CTGTGCGGACTTTGGCACATTTGA \\
\hline \multirow[t]{2}{*}{$\mathrm{C} 05 \mathrm{C} 10.5$} & ce0004L & GAACTATTTGTGCGCGCGCGTTT \\
\hline & ce0004R & TCAATGAGTGGGGTGGATTCAAGAAGA \\
\hline \multirow[t]{2}{*}{ C43EII.2 } & ce0006-3L & CTCCGAAATGAGAACTGTCCGACCAAT \\
\hline & ce0006-3R & AAAGCTGAAGAAGTCGAATCGGTGCAT \\
\hline \multirow[t]{2}{*}{ Y69A2AR.30 } & ce0007L & CGCGATTTCCCTCAAAGGATCTGC \\
\hline & ce0007R & AGAGCACCATCACACCACCTGACG \\
\hline \multirow[t]{2}{*}{$\mathrm{F} 25 \mathrm{H} 2.13$} & ce0008L & TCAAAAAGAGACGAAGCCGCTGGA \\
\hline & ce0008R & GCAGCAGCAACATCTTGAGCGTGT \\
\hline \multirow[t]{2}{*}{$\mathrm{M} 03 \mathrm{CII} .2$} & ce0009-2L & CAGCTCAGCTTCTCGTGGAGACCCTAT \\
\hline & ce0009-2R & AGGAATCTTTAGAGCAACCGGGCAAAA \\
\hline \multirow[t]{2}{*}{ C47DI 2.8} & ce00IOL & CCGGAATCGCATTGATTCCAAAAG \\
\hline & ce00IOR & TGCAGCGAAATCACTTACAATCGTTTCC \\
\hline \multirow[t]{2}{*}{ C05DII.II } & ce00IIL & CGCCACAAGTACACCAACAACGAGAA \\
\hline & ce00IIR & GCGAGATCAGCGACGTCTTTCTTGA \\
\hline
\end{tabular}

from our study since a mutation was never followed unless it appeared in at least one channel in both row and column pool gels.

\section{Selection of targeted regions}

Mutations identified through TILLING are randomly distributed in the genome, thus making it possible to target genes of any size and at any location [23]. The average size of the region that is tested in one TILLING screen is usually about $1500 \mathrm{bp}$ and this is the size that was used for most genes in this study (Table 1). For the gene C05C10.5 whose genomic sequence is only 788 bp we designed primers that amplified a region of approximately $1200 \mathrm{bp}$ to avoid screening excess intergenic DNA upstream or downstream of the locus where mutations would have a higher probability of being silent. In addition, for gene mus-81 C43E11.2, the primer sets that we designed to amplify a product of 1500 bp gave multiple amplification bands when used with our standard PCR conditions. Thus we were forced to use a primer set that amplified a smaller region in order to obtain a single, clean PCR product from this locus.

For genes that are much larger than $1500 \mathrm{bp}$, two approaches have been used for TILLING in other systems. The web-based programme, CODDLE [39] was originally designed for use in the Arabidopsis thaliana TILLING project and assists researchers in designing primers to select regions of a gene of interest that are most likely to provide loss-of-function or deleterious alleles. Researchers also have the option of requesting that CODDLE design primers that will amplify a fragment within a specific region of the gene in which they are most interested, for example, a specific domain that is known to interact with another gene or protein. A different approach was used for a recent Drosophila melanogaster TILLING project [29]. In this study, multiple primers were designed to amplify overlapping fragments of a gene so that the entire gene could be screened by TILLING. For our TILLING project in C. elegans, as mentioned previously, the average amplicon size was $1500 \mathrm{bp}$ and primers were designed to amplify the region of the gene predicted by CODDLE to be most susceptible to EMS-induced mutations. Primer sequences used in this study are listed in Table 3. For C. elegans, where the average gene size is $3000 \mathrm{bp}$ and introns are generally small [40], TILLING should prove to be even more efficient than in other species where larger genes and intervening sequences are the norm. Indeed, $62 \%$ of mutations recovered in this $C$. elegans screen are predicted to have an effect on the protein product (Table 2), although long-term studies are required to determine exactly how many of these mutations will result in a mutant phenotype.

\section{Identification of individual mutant animals}

Each $F_{1}$ mutagenised line was frozen individually in order to ensure that identified mutations could be recovered even if a sample was frozen and thawed multiple times (see Figure 2). Except in the case of deleterious mutations that affect viability or reproduction, each mutant allele that is heterozygous in the $F_{1}$ parent is expected to be present in 3/4 of the progeny of this individual. If the mutant allele is recessive lethal, then the frequency of progeny carrying this allele should be $2 / 3$. In this study we 
A)

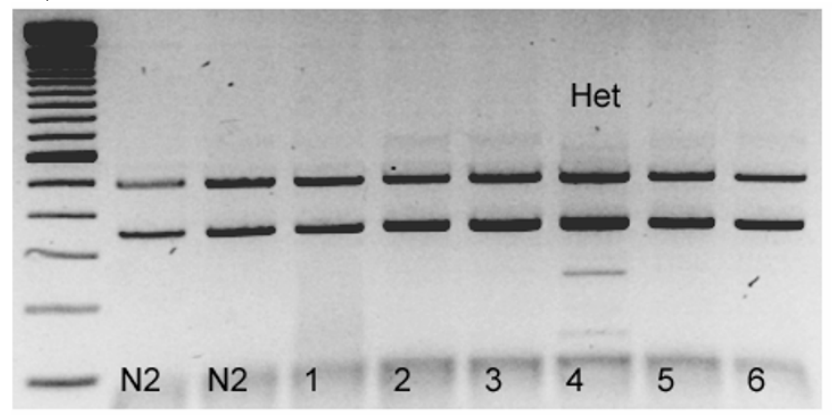

B)

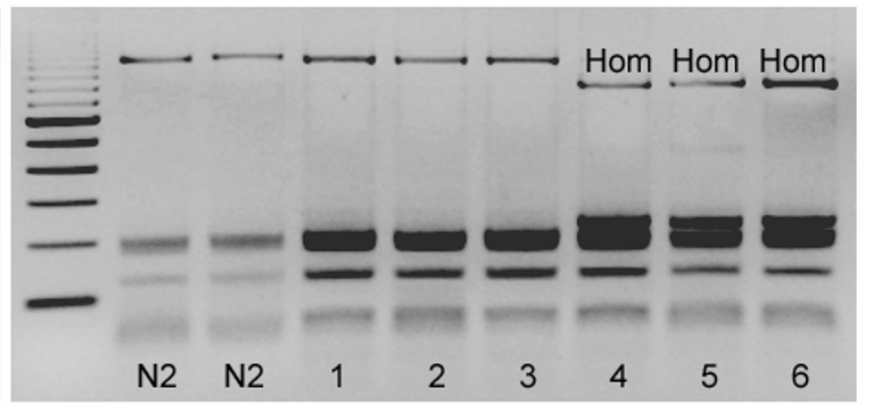

\section{Figure 4}

Restriction enzyme digests of DNA from heterozygous and homozygous mutants. A) CAPS analysis of sibling lines for CN646 $h t p-3(\mathrm{vcl})$ using the restriction enzyme Taql. The lanes labelled N2 are wildtype controls. Lane marked 4 exhibits additional bands when digested with this enzyme indicating this line is heterozygous for the vcl mutation. B) CAPS analysis of sibling lines for CN7II mdf-2(vcl5), using the restriction enzyme Hinfl. The lanes labelled N2 are wildtype controls. Lanes marked 4, 5 and 6 show additional cleavage bands and are missing the wildtype band indicating that they are homozygous for the vcl 5 mutation.

were able to recover individual descendants of $\mathrm{F}_{2}$ worms carrying the mutant alleles in 19 of the 20 strains thawed for testing. The remaining strain proved to be a false positive isolated from our screening of our first library. The probability of this type of error occurring with our current methodology of screening both row and column pools is very low.

There are several methods that can be used to follow the segregation of point mutations in $\mathrm{F}_{2}$ and subsequent populations. We used three different strategies for comparison in this study: TILLING, cleaved amplified polymorphic sequences (CAPS) [41], and direct sequencing. TILLING was the most expensive and labour-intensive method because of the requirement to purify the extracted DNA for PCR and because detection of homozygous individuals necessitated duplexing the DNA from the putative mutant with wildtype DNA (since fragments are only cleaved with CJE if there is a mismatch in the DNA). In addition, multiple rounds of TILLING were sometimes necessary if one of the two reactions (duplexed and nonduplexed DNA) failed, because in such a case the zygosity of the animal in question could not be determined. CAPS was tried if the PARSESNP programme ([42] indicated one or more restriction enzyme polymorphisms between the mutant and wildtype sequences (Figure 4). Sixty of the 71 mutations we identified ( $85 \%$ ) in this screen are of this type. For the samples where there were no restriction enzyme polymorphisms either TILLING or direct sequencing was used to detect mutant individuals because of time constraints, although studies have shown that the derived cleaved amplified polymorphic sequences (dCAPS) technique works well and would be a less expen- sive method for following mutations in the long-term [43].

Results from direct sequencing of DNA from $\mathrm{F}_{2}$ descendants of mutant animals showed that the mutation of interest was present in an average of two out of three of the thawed progeny ( 43 out of 64 samples), although this varied from a low of one out of eight with F25H2.13(vc9), and a high of 13 out of 16 with htp-3 F57C9.5(vc2). Both of these alleles with non-typical segregation patterns are missense mutations and, although the $v c 2$ allele does not have an obvious phenotype in homozygous mutants, we speculate that it may be incompatible with the wildtype allele of this locus since heterozygous individuals carrying both mutant and wildtype alleles together were never recovered. The high frequency of homozygous $v c 2$ mutants compared to wildtype individuals may just be a statistical anomaly or may indicate that the mutant protein confers some type of fitness advantage upon animals carrying it.

Two other mutations, F25H2.13(vc10) and mel-32 C05D11.11(vc11), were apparently homozygous in the parent $F_{1}$ strains in which these alleles were detected because all of the thawed progeny from the $\mathrm{F}_{2}$ plates were found to be homozygous for these mutations. All other mutations were heterozygous in the $F_{1}$ generation, as expected, because EMS-induced damage in C. elegans usually occurs in either the $\mathrm{P}_{0}$ egg or the $\mathrm{P}_{0}$ sperm before fertilization. Neither of the homozygous mutations was present as a background mutation in the wildtype strain used for mutagenesis, or in any of the other mutant strains whose DNA was sequenced. The $\mathrm{F}_{1}$ homozygosity of $v c 10$ 
and $v c 11$ may be the result of an early mitotic crossover or other heritable event that occurred in the developing zygote rather than in the maternal germ cells, during or after EMS mutagenesis. The fact that these mutations were detectable at all using TILLING is curious since a DNA mismatch is needed for cleavage with CJE. In the pooled samples, adequate wildtype DNA from other samples would have been amplified and paired with the mutant DNA for cleavage to occur, but when testing the DNA from the individual $\mathrm{F}_{1}$ animals no wildtype DNA should have been present since we did not detect any wildtype progeny from these animals. It is possible that only the germ cells of the $F_{1}$ animal carried the mutations identified in our screen and that wildtype DNA from the somatic cells of this animal was sufficient to allow for cleavage with CJE when amplified using PCR. It is also possible that some wildtype DNA contamination was present in these reactions and was amplified along with the homozygous DNA from the mutant. The fact that the cleavage bands were very faint on the TILLING gels is consistent with either of these ideas.

An additional polymorphism in gene F25H2.13 was identified when sequencing other alleles of this gene and found to be homozygous in all TILLING strains and in the $\mathrm{N} 2 \mathrm{P}_{0}$ strain utilised for mutagenesis in this study, making it clear that this strain is different from the N2 strain used in the C. elegans genome sequencing project. Although this polymorphism induces an amino acid change in the protein sequence, it has no obvious effect on gene function since animals carrying the polymorphism are seemingly wildtype.

\section{Analysis of mutants identified through TILLING}

Some of the loci chosen as candidates for this pilot project were genes that are thought to play roles in chromosome segregation, recombination or genome maintenance. In some cases, RNAi constructs of these genes had been shown to induce varying phenotypes, and we reasoned that null and missense alleles of these targets would allow us to better identify the true function of these genes. In other cases, the genes we targeted had no known RNAi phenotype, but had been implicated in meiotic functions through two-hybrid or bioinformatics studies.

Examination of the sequence of the 71 alterations shown in Table 2 revealed that 27 of the changes resulted in no amino acid change (silent mutations) and these strains are unlikely to have visible phenotypes. Of the remaining 44 mutations resulting in amino acid changes, 24 affected charged or conserved residues. These are the alleles that are most likely to affect the functioning of the gene product and thus most likely to have phenotypic changes. We have done preliminary phenotypic analysis on 25 of the TILLING alleles we identified and observed phenotypes for 16 of these alleles. Although further studies are needed to confirm these data, the TILLING alleles reported here clearly allow characterisation of these genes in a manner that was not previously possible.

mel-32 C05DII.II

The gene, mel-32 C05D11.11 was selected simply as a control because many mutations at this locus have been identified through forward genetic screens and sequencing of these indicates that most of the amino acids in the encoded protein are essential for normal gene function [46]. Mutations in this gene result in a maternal-effect lethal phenotype (Mel). The homozygotes are viable and fertile, but produce eggs that fail to hatch. The putative null allele isolated by TILLING (vc68) does indeed have a Mel phenotype. The three remaining missense alleles are currently being examined, although preliminary evidence indicates that one of them ( $\mathrm{vc} 11)$ is a conservative change that does not appear to confer any mutant phenotype.

\section{$\mathrm{C} 05 \mathrm{Cl} 0.5$}

A gene name has not yet been assigned for this locus (indicated by ${ }^{*}$ in Table 1). Little is known about this gene or the function of the gene product. RNAi treatment produces variable results ranging from embryonic lethality to high incidence of males (Him). We have two TILLed alleles ( $v c 21$ and $v c 40)$ that were isolated as heterozygotes and are being maintained as such. As a consequence we have not yet determined whether or not these alleles will cause a mutant phenotype.

\section{mus-8I C43EII.2}

We have isolated the first genetic mutations in this gene through TILLING. Three of the missense mutations ( $v c 42$, $v c 46$ and $v c 47$ ) have a radiation-sensitive (Rad) phenotype. The mutant strains, which can be maintained as homozygotes, vary in the severity of their response to radiation, and thus will provide valuable resources for dissecting the molecular characteristics of this gene. Homozygous $m u s-81(v c 46)$ animals are severely radiation sensitive, while animals carrying either mus-81(vc42) or mus-81(vc47) exhibit less severe phenotypes. These phenotypes are consistent and continue to segregate with the molecular mutations even after multiple outcrossings.

\section{xpf-I C47D / 2.8}

This gene is the C. elegans orthologue of the essential nucleotide excision repair gene XPF/ERCC4 [48]. We have identified three mutations in this gene $(v c 18, v c 19$ and $v c 67)$. All of these are missense alleles, and we have determined that two of them ( $v c 19$ and $v c 67)$, have a Rad phenotype as would be predicted. None of the alleles is lethal since they can be maintained as homozygotes. 


\section{$\mathrm{F} 25 \mathrm{H} 2.13$}

A gene name has not yet been assigned for this locus (indicated by $*$ in Table 1 ), but it is predicted to encode a DEAD helicase closely related by sequence to DOG-1. RNAi treatment reveals no detectable phenotype and the deletion allele (tm1866) is listed in Wormbase [7] as homozygous viable. We have identified five new missense alleles through TILLING, and strains carrying these alleles are also viable although they appear to have reduced brood sizes.

\section{htp-3 F57C9.5}

Excellent antibodies are available for studying the protein product of this HIM-3 paralogue in vivo, but the deletion allele $h t p-3(g k 26)$ is associated with a complex rearrangement that includes a wild-type copy of the gene, making phenotypic analysis impossible. RNAi experiments revealed that the animals exhibit no phenotype when the worms are fed a dsRNA construct for $h t p-3$ F57C9.5 [44], but injection of the dsRNA results in severe embryonic lethality as a consequence of chromosome nondisjunction [45]. We have isolated five new missense alleles of this gene by TILLING, and observed varying levels of embryonic lethality that segregate with the mutant allele for three of these mutations ( $v c 1, v c 75$ and $v c 77)$.

\section{$\mathrm{M03Cl} 1.2$}

A gene name has not yet been assigned for this locus (indicated by * in Table 1), but the gene is a member of the DEAD helicase family related to DOG-1. RNAi treatment produces arrested embryos, and a deletion allele ( $t m 2188$ ) has been shown to be sterile, but we have not yet determined whether any of the missense alleles we have identified by TILLING have phenotypes.

\section{cki-2 T05A6.2}

The knockout allele of this gene cki-2(ok741) causes sterility in homozygous animals as does the TILLING mutation cki-2(vc39) which affects a conserved splice junction site. The strain is easily maintained as a heterozygote, however, and can used for genetic analysis in this way.

\section{mdf-2 Y69A2AR.30}

This gene was studied previously using RNAi and shown to have reduced brood size and increased incidence of males [47]. Using TILLING, we have successfully identified the first genetic mutation in this gene. The maf2(vc15) mutation can be maintained homozygously despite exhibiting reduced brood size and high incidence of males, and thus provides a valuable tool for the study of metaphase to anaphase checkpoint signalling.

\section{htp-2 Y73B6BL.2}

This gene encodes a paralogue of HIM-3 and has been shown to play a role in meiotic function. RNAi treatment produces a Him phenotype. We have five TILLed alleles of this locus that are viable as homozygotes and for which we have observed no obvious phenotype.

One of the major advantages of TILLING is that it can not only identify null mutations which eliminate the function of the gene product entirely, but also missense alleles that result in a partial loss or change of gene function and which can allow disruption of specific domains within a gene and are especially useful for suppressor screens which can be used to identify interacting genes. The reverse genetic techniques that are presently being used in C. elegans are all more likely to result in complete-loss-offunction alleles which, if the effect is lethal or detrimental, may limit the analysis that can be done. With TILLING, however, it is possible to use missense mutations in different regions of the gene for the dissection of multiple functions and interactions of a given gene product. While the point mutations that TILLING identifies can result in complete loss-of-function alleles that are as effective as deletions in knocking out gene function, this technique can also identify partial loss-of-function alleles or other alterations of gene function that can be extremely useful for investigating the function of essential genes or genes encoding proteins with multiple domains. A well-known example illustrating the value of an allelic series of mutations is the elucidation of the functions of the let- 60 gene of C. elegans which encodes a member of the GTP-binding RAS proto-oncogene family involved in signalling (reviewed in [49]. Different mutations in this gene can have recessive, semi-dominant, or dominant phenotypes that define functions for the protein in developmental processes as diverse as vulval induction, migration of the sex myoblasts, function of chemosensory neurons, progression through pachytene in meiosis I, and differentiation of the excretory cell. Thus, a comprehensive understanding of the biology of a given gene is often revealed using non-null mutations. In this study we have identified 42 new missense mutations and two nonsense mutations that are available for genetic studies, and preliminary analysis indicates that at least some of these have deleterious effects on phenotype.

\section{Conclusions}

We have used TILLING in C. elegans to determine the spectrum of mutations induced by EMS in this species and found that $96 \%$ of the mutations we identified were $\mathrm{G} / \mathrm{C}$ to-A/T transitions. In this pilot project we identified 71 point mutations in 10 genes, of which 44 or more may have an effect on gene function. For seven of the genes we targeted no mutant strains were previously available from the Caenorhabditis Stock Centre. One of the remaining target genes had a deletion mutation, but the strain carrying this mutation was shown to also carry a wildtype copy of the gene. Hence, for eight of the 10 target genes screened, 
TILLING has provided the first genetically heritable mutations which can be used to study their functions in vivo.

A frozen library of more than 1500 EMS-mutagenised worms was constructed, and enough DNA has been extracted and purified to screen for mutations in more than 5000 genes. The initial construction of the mutant library is labour-intensive but, if well-constructed, it should only be necessary to perform this step once. Approximately one gene, per Li-cor sequencer, per week can be screened after library construction is complete. The cost and rate of TILLING is dependent partially on the quality of the DNA being screened (how reliably the reactions work) and the mutation rate (how many alleles are identified per pooled population). Current estimates of cost-per-gene vary from $\$ 1500$ to $\$ 2500$ USD, including equipment, labour and consumables.

TILLING appears to provide a reasonably high proportion of missense mutations in C. elegans probably, in part, because of the small size of $C$. elegans introns compared to some other species. With EMS, the expected frequency of nonsense and splice junction mutations from TILLING screens is approximately five percent in most species. The two putative null alleles of this type that we have identified (out of 71 mutations) represent a frequency not significantly different from the expected five percent. At the CAN-TILL facility TILLING is successfully being used in many species for the detection of both induced and natural variation (reviewed in [50]) and there appears to be no species bias in terms of performance. It would seem, however, to be especially useful for genetically tractable organisms such as $C$. elegans where genomics tools are well developed, but where reverse genetics techniques that can provide heritable mutations suitable for genetic analysis lag far behind.

\section{Methods}

\section{Mutagenesis and library construction}

N2 wild type hermaphrodites were exposed to $0.025 \mathrm{M}$ EMS for $4 \mathrm{~h}$ (as in Brenner, 1974 [51], but at a lower EMS concentration). After exposure to mutagen, the worms were washed and allowed to recover for 1-2 h before young gravid hermaphrodites were picked to fresh plates (10 per plate). After $24 \mathrm{~h}$, the mutagenised $\mathrm{P}_{0}$ animals were transferred to fresh plates for a second $24 \mathrm{~h}$ brood. $\mathrm{F}_{1}$ progeny were picked 1 per plate and allowed to self-fertilize. The $\mathrm{F}_{1}$ progeny of mutagenised worms were set up individually rather than in pooled populations so as to ultimately simplify the isolation of $\mathrm{F}_{3}$ animals carrying any mutations. This was considerably more work than would have been required with pooled $\mathrm{F}_{1}$ samples but, because worm libraries were frozen, the extra work was a one time occurrence and greatly simplified identification of thawed mutants. When the mutagenised worm popula- tions had exhausted the bacteria on the plate, worms were washed off each plate with $2 \mathrm{ml}$ of M9 buffer. One third of the population from each $\mathrm{F}_{1}$ line was used for DNA and the other two thirds was frozen for future use as follows: from each plate, $0.5 \mathrm{ml}$ of worms were mixed with $0.5 \mathrm{ml}$ of $2 \mathrm{X}$ freeze solution $\left(100 \mathrm{mM} \mathrm{NaCl}, 50 \mathrm{mM} \mathrm{KPO}_{4} \mathrm{pH}\right.$ $6.0,0.3 \mathrm{mM} \mathrm{MgSO}_{4}, 30 \%$ glycerol) and frozen at $-80^{\circ} \mathrm{C}$ to generate a frozen library stock.

The remaining $1 \mathrm{ml}$ of worms in $\mathrm{M} 9$ buffer for each line was centrifuged at 14,000 g to pellet worms. Excess buffer was aspirated leaving approximately $50 \mu \mathrm{l}$ of buffer and worms in each tube. $50 \mu \mathrm{l}$ of worm lysis buffer $(50 \mathrm{mM}$ $\mathrm{KCl}, 10 \mathrm{mM}$ Tris ( $\mathrm{pH} 8.3$ ), $2.5 \mathrm{mM} \mathrm{MgCl} 2,0.45 \%$ Nonidet P-40, 0.45\% Tween 20, 0.01\% (w/v) gelatin, and 10 $\mathrm{mg} / \mathrm{ml}$ proteinase $\mathrm{K}$ ) was added to each tube which was then frozen at $-80^{\circ} \mathrm{C}$ for at least $1 \mathrm{~h}$. DNA was extracted by proteinase $\mathrm{K}$ lysis at $57^{\circ} \mathrm{C}$ for $4 \mathrm{~h}$ with occasional vortexing, and then $100 \mu \mathrm{l}$ of phenol:chloroform:isoamyl alcohol (24:24:1) solution was added to the crude DNA extracts and tubes were vortexed for 5 minutes. Phases were separated by centrifugation at $14,000 \mathrm{~g}$ for 5 minutes and then aqueous layer was removed to a fresh tube containing $100 \mu \mathrm{l}$ of chloroform, vortexed for 5 minutes and the phases separated by centrifugation at $14,000 \mathrm{~g}$. The aqueous layer was again removed to a fresh tube containing $400 \mu \mathrm{l}$ of isopropanol, and then the DNA was precipitated by centrifugation at $14,000 \mathrm{~g}$ for 10 minutes. DNA pellets were washed once with $70 \%$ ethanol, resuspended in 50 to $100 \mu \mathrm{ldd} \mathrm{H}_{2} \mathrm{O}$ and quantified using a ND-1000 Spectrophotometer (NanoDrop Technologies, Wilmington, DE, USA). Samples were diluted to $1 \mathrm{ng} / \mathrm{ul}$ in $10 \mathrm{mM}$ Tris, $1 \mathrm{mM}$ EDTA pH 7.4, and $1 \mathrm{ml}$ aliquots were distributed in plates of 64 samples ( 8 rows by 8 columns) before pooling. The DNA samples were then pooled 8-fold, in both column and row directions, and then distributed into 96-well plates of 8-fold column pools and 96-well plates of 8-fold row pools for each library of 768 individuals.

\section{Primer design and PCR Amplification}

Primers were designed, using the web-based programme CODDLE [39] and selecting "EMS (not TILLING)" as the Mutation Method since a C. elegans option was not available and we did not know how similar the spectrum of mutations caused by EMS was in C. elegans compared to other organisms. Primers for C05C10.5 were designed to amplify a fragment of approximately 1200 bp since the genomic size of this gene is only $788 \mathrm{bp}$. The other primer sets were designed to amplify fragments as close to 1500 bp as possible, given the structure of the DNA in the region. Primers were purchased from MWG Biotech, Inc. (High Point, NC, USA), suspended to a concentration of $100 \mathrm{uM}$ in $10 \mathrm{mM}$ Tris, $1 \mathrm{mM}$ EDTA pH 7.4 and used at a final concentration of $0.2 \mathrm{mM}$ in a mixture of $3: 2$ 
(labeled:unlabeled) for the forward (IRD700-labeled) primers and 4:1 (labeled:unlabeled) for the reverse (IRD800-labeled) primers as per Colbert et al., 2001 [52]. PCR was also performed according to Colbert et al.,2001 [52]: $10 \mathrm{ul} \mathrm{PCR}$ reactions with $2.5 \mathrm{ng}-5 \mathrm{ng}$ of genomic DNA were used for amplification in 96-well or 384-well PCR plates using ExTaq polymerase (Takara Bio Inc, Japan), but with 0.6 times the recommended concentration of ExTaq buffer and $2 \mathrm{mM} \mathrm{MgCl}_{2}$. PCR cycles were as follows: $95^{\circ} \mathrm{C}$ for $2 \mathrm{~min}$; eight cycles of $\left[94^{\circ} \mathrm{C}\right.$ for $20 \mathrm{sec}$, $73^{\circ} \mathrm{C}$ for $30 \mathrm{sec}$ (decrementing $1^{\circ} \mathrm{C}$ per cycle), $72^{\circ} \mathrm{C}$ for 1 min]; 45 cycles of: $\left[94^{\circ} \mathrm{C}\right.$ for $20 \mathrm{sec}, 65^{\circ} \mathrm{C}$ for $30 \mathrm{sec}$, and $72^{\circ} \mathrm{C}$ for $\left.1 \mathrm{~min}\right] ; 72^{\circ} \mathrm{C}$ for $5 \mathrm{~min} ; 99^{\circ} \mathrm{C}$ for $10 \mathrm{~min}$ (denaturation and inactivation of taq enzyme); and 70 cycles of $20 \mathrm{sec}$ at $70^{\circ} \mathrm{C}$ (decrementing $0.3^{\circ} \mathrm{C}$ per cycle for random reannealing to allow hybridisation of mutant and wildtype molecules), hold at $4{ }^{\circ} \mathrm{C}$.

\section{Preparation of celery juice extract}

Crude celery juice extract (CJE) was prepared as described by Till et al. [53]. Briefly, $0.5 \mathrm{~kg}$ of celery was processed in a kitchen-quality juicer until liquefied. Tris $\mathrm{HCl}$ (pH 7.7) was added to $0.1 \mathrm{M}$ along with Phenylmethylsulphonylfluoride (PMSF) to $100 \mathrm{mM}$. The solution was spun at $2600 \mathrm{G}$ for 20 minutes and the supernatant removed, brought to $25 \%$ saturation in $\left(\mathrm{NH}_{4}\right)_{2} \mathrm{SO}_{4}$, mixed for 30 minutes at $4{ }^{\circ} \mathrm{C}$, and spun at $15,000 \mathrm{G}$ for 40 minutes at $4^{\circ} \mathrm{C}$. The supernatant was removed again and adjusted to $80 \%$ saturation in $\left(\mathrm{NH}_{4}\right)_{2} \mathrm{SO}_{4}$, mixed for 30 minutes at $4{ }^{\circ} \mathrm{C}$, and spun at $15,000 \mathrm{G}$ for 1.5 hours at $4^{\circ} \mathrm{C}$. The pellet from this cut was resuspended in $1 / 10$ the starting volume of $0.1 \mathrm{M}$ Tris $\mathrm{HCl}$ (pH 7.7), $100 \mathrm{mM}$ PMSF. The suspension was dialysed against $8 \mathrm{~L}$ of the same buffer, four times, for one hour each time at $4{ }^{\circ} \mathrm{C}$ using Spectrapore dialysis tubing (10,000 MW cut-off). Aliquots were stored at $-70^{\circ} \mathrm{C}$ and were spun at approximately $2000 \mathrm{G}$ for one minute before use to remove any tissue debris.

\section{CJE digestion, sequence analysis and identification of mutants}

PCR products were digested with CJE by adding $20 \mu \mathrm{l}$ of extract and buffer mix (100 mM MgSO 4, $100 \mathrm{mM}$ HEPES, $300 \mathrm{mM} \mathrm{KCl}, 0.02 \%$ Triton X-100, $0.002 \mathrm{mg} / \mathrm{ml} \mathrm{BSA}$, and $0.2 \%$ to $0.3 \%$ crude CJE) directly to the PCR reactions and incubating at $45^{\circ} \mathrm{C}$ for 15 minutes. Reactions were stopped by adding $2.5 \mu \mathrm{l}$ of $0.5 \mathrm{M}$ EDTA. The DNA was purified by passage through G50 Sephadex in 96-well Millipore Multiscreen ${ }^{\circledast}$ filtration plates (Millipore Corporation, Billerica, MA) and concentrated for 30 minutes at $90^{\circ} \mathrm{C}$ before running on a $25 \mathrm{~cm}$ long LI-COR acrylamide gel with a $0.4 \mathrm{~mm}$ wide, 96-well sharkstooth comb. Analysis of the gel images was done using GelBuddy [54] to define lanes and estimate sizes of cleavage products. The correlation of row and pool columns indicated which individual $\mathrm{F}_{1}$ worm carried the mutation. Most mutations were sequenced in both directions using either the same forward or reverse primers as for PCR or an internal primer designed for sequencing. Sequence analysis was performed using Sequencher 4.2 (Gene Codes Corporation, Ann Arbor, MI, USA) and the potential effect of the mutations was predicted using PARSESNP [42].

\section{Pooling}

DNA from 4 strains previously shown to carry a single mutation each was screened to test the efficiency of different pooling depths. Four bands were expected in each of the two channels of the Li-cor sequencing image when amplified DNA from these individuals was run on a gel. With 4-fold pooling all eight mutant bands were detected (four in the 700 channel image and four in the 800 channel image), as they were with the 8 -fold pools, whereas with 12-fold pooling, six of the eight mutant bands were seen on one test gel (three in the 700 channel image and three in the 800 channel image), and only three bands on the second gel (two in the 700 channel image and one in the 800 channel image). Based on these data and data from other studies, we conclude that 8 -fold pooling was the best option for C. elegans.

\section{Identification of mutant individuals}

Frozen worms were thawed and 20 individuals were plated 1 per $60 \mathrm{~mm}$ NGM plate and allowed to self-fertilize. Two approaches were taken to identify lines containing the target mutation. In the first approach, the 20 individuals from the strain carrying the mutation of interest were plated individually, allowed to grow until plates were starved, and DNA was prepared as described for the DNA library construction. In the second approach, individual animals from the strain carrying the mutation of interest were allowed to lay eggs for 2-3 days, and then the parent was picked into $5 \mu$ l of lysis buffer and lysed at $57^{\circ} \mathrm{C}$ for $1 \mathrm{~h}$ followed by $95^{\circ} \mathrm{C}$ for $15 \mathrm{~m}$ to inactivate the proteinase $\mathrm{K}$. In both approaches the extracted DNA was PCR amplified and the mutation detected either by TILLING, or by direct sequencing of the amplified DNA, or by digestion of the PCR product with restriction enzymes resulted in a banding pattern different from wild type. Restriction enzyme site changes were found by PARSESNP to occur in 60 of 71 mutations.

If homozygous lines were not identified, 20 more individuals were set up from one line that had been shown to be heterozygous and the progeny from each of these lines was screened for evidence of deleterious mutations that might result in inviability. If sterile adults, dead embryos or larval lethals were observed, DNA was prepared from these and tested for the presence of the targeted mutation. Mutations that segregated with inviable phenotypes were balanced with genetic balancers to prevent the loss of the mutation. 


\section{Statistical comparison of results from TILLING in different organisms}

Frequencies of EMS-induced mutations identified during different TILLING experiments have been based on different samples sizes in different species. When comparing our data with others we used an on-line Proportions Test [55] to compare the frequencies we observed with those reported in other species and determine whether or not observed differences were significant (at the $90 \%$ confidence level) or were simply likely to be the result of sample size differences.

\section{List of abbreviations used \\ bp: base pair(s);}

CAPS: cleaved amplified polymorphic sequences;

CJE: celery juice extract;

dCAPS: derived cleaved amplified polymorphic sequences;

dsRNA: double stranded RNA;

EMS: ethylmethanesulfonate;

RNAi: RNA interference;

TILLING: Targeting Induced Local Lesions in Genomes;

TMP/UV: trimethylpsoralen and ultraviolet radiation

\section{Authors' contributions}

EJG and MCZ conceived of the study. GWH participated in its design and coordination. AMR and NJO carried out the mutagenesis and culturing of nematode strains. EJG performed the TILLING and data analysis and wrote the manuscript. MCZ and NJO analysed mutant phenotypes. All authors read and approved the final manuscript.

\section{Additional material}

\section{Additional File 1}

Table in MS Word that shows a list of mutations identified in forward genetic screens of EMS-treated C. elegans (obtained from Wormbase [7]).

Click here for file

[http://www.biomedcentral.com/content/supplementary/14712164-7-262-S1.doc]

\section{Acknowledgements}

This work was supported by Canadian Institutes for Health Research (CIHR) grants to GWH, MCZ, and AMR, and by Natural Sciences and Engineering Research Council of Canada (NSERC) funding to AMR. The authors would like to especially acknowledge the efforts of Sanja Tarailo and Shir Hazhir during library construction and sibbing analysis. We are also grateful to Quentin Cronk and the UBC Botanical Garden and Centre for

Plant Research for laboratory space provided to CAN-TILL.

\section{References}

I. Hodgkin J: Introduction to genetics and genomics (September 6, 2005). WormBook 2005 [http://www.wormbook.org]. The C. elegans Research Community

2. Barr MM: Super models. Physiol Genomics 2003, 13:15-24.

3. Hariharan IK, Haber DA: Yeast, flies, worms, and fish in the study of human disease. N Engl J Med 2003, 348:2457-2463.

4. Link CD: Invertebrate models of Alzheimer's disease. Genes Brain Behav 2005, 4: 147-156.

5. Tamas I, Hodges E, Dessi P, Johnsen R, Vaz Gomes A: A combined approach exploring gene function based on worm-human orthology. BMC Genomics 2005, 6:65.

6. Lai C, Chou C, Ch'ang L, Liu C, Lin W: Identification of Novel Human Genes Evolutionarily Conserved in Caenorhabditis elegans by Comparative Proteomics. Genome Res 2000, 10:703-713.

7. Chen N, Harris TW, Antoshechkin I, Bastiani C, Bieri T, Blasiar D, Bradnam K, Canaran P, Chan J, Chen CK, Chen WJ, Cunningham F, Davis P, Kenny E, Kishore R, Lawson D, Lee R, Muller HM, Nakamura C, Pai S, Ozersky P, Petcherski A, Rogers A, Sabo A, Schwarz EM, Van Auken K, Wang Q, Durbin R, Spieth J, Sternberg PW, Stein LD: WormBase: a comprehensive data resource for Caenorhabditis biology and genomics. Nucleic Acids Res 2005, 33:D383-9 [http://www.wormbase.org].

8. Hillier LW, Coulson A, Murray JI, Bao Z, Sulston JE, Waterston RH: Genomics in C. elegans: so many genes, such a little worm. Genome Res 2005, I 5: 165I-1660.

9. Wei C, Lamesch P, Arumugam M, Rosenberg J, Hu P, Vidal M, Brent MR: Closing in on the C. elegans ORFeome by cloning TWINSCAN predictions. Genome Res 2005, I 5:577-582.

10. Li S, Armstrong CM, Bertin N, Ge H, Milstein S, Boxem M, Vidalain PO, Han JD, Chesneau A, Hao T, Goldberg DS, Li N, Martinez M, Rual JF, Lamesch P, Xu L, Tewari M, Wong SL, Zhang LV, Berriz GF, Jacotot L, Vaglio P, Reboul J, Hirozane-Kishikawa T, Li Q, Gabel HW, Elewa A, Baumgartner B, Rose DJ, Yu H, Bosak S, Sequerra R, Fraser A, Mango SE, Saxton WM, Strome S, Van Den Heuvel S, Piano F, Vandenhaute J, Sardet C, Gerstein M, Doucette-Stamm L, Gunsalus KC, Harper JW, Cusick ME, Roth FP, Hill DE, Vidal M: A map of the interactome network of the metazoan C. elegans. Science 2004, 303:540-543.

II. Reisner K, Asikainen S, Vartiainen S, Wong G: Developmental and Biological Insights Obtained from Gene Expression Profiling of the Nematode Caenorhabditis Elegans. Curr Genomics 2005, 6:97-107.

12. Stein LD, Bao Z, Blasiar D, Blumenthal T, Brent MR, Chen N, Chinwalla A, Clarke L, Clee C, Coghlan A, Coulson A, D'Eustachio P, Fitch DH, Fulton LA, Fulton RE, Griffiths-Jones S, Harris TW, Hillier LW, Kamath R, Kuwabara PE, Mardis ER, Marra MA, Miner TL, Minx P, Mullikin JC, Plumb RW, Rogers J, Schein JE, Sohrmann M, Spieth J, Stajich JE, Wei C, Willey D, Wilson RK, Durbin R, Waterston RH: The genome sequence of Caenorhabditis briggsae: a platform for comparative genomics. PLoS Biol 2003, I:E45.

13. Schwarz EM: Genomic classification of protein-coding gene families (September 23, 2005). WormBook 2005 [http:// www.wormbook.org]. The C. elegans Research Community

14. Fire A, Xu S, Montgomery MK, Kostas SA, Driver SE, Mello CC: Potent and specific genetic interference by double-stranded RNA in Caenorhabditis elegans. Nature 1998, 391:806-8I I.

15. Gonczy P, Echeverri C, Oegema K, Coulson A, Jones SJ, Copley RR, Duperon J, Oegema J, Brehm M, Cassin E, Hannak E, Kirkham M, Pichler S, Flohrs K, Goessen A, Leidel S, Alleaume AM, Martin C, Ozlu N, Bork P, Hyman AA: Functional genomic analysis of cell division in C. elegans using RNAi of genes on chromosome III. Nature 2000, 408:331-336.

16. Maeda I, Kohara $Y$, Yamamoto M, Sugimoto A: Large-scale analysis of gene function in Caenorhabditis elegans by high-throughput RNAi. Curr Biol 200 I, I I: I7|-I76.

17. Kamath RS, Martinez-Campos M, Zipperlen P, Fraser AG, Ahringer J: Effectiveness of specific RNA-mediated interference 
through ingested double-stranded RNA in Caenorhabditis elegans. Genome Biol 200I, 2:RESEARCH0002.

18. Timmons $L$, Fire $A$ : Specific interference by ingested dsRNA. Nature 1998, 395:854.

19. Zwaal RR, Broeks A, van Meurs J, Groenen JT, Plasterk RH: Targetselected gene inactivation in Caenorhabditis elegans by using a frozen transposon insertion mutant bank. Proc Natl Acad Sci USA 1993, 90:7431-7435.

20. Williams DC, Boulin T, Ruaud AF, Jorgensen EM, Bessereau JL: Characterization of Mos I-mediated mutagenesis in Caenorhabditis elegans: a method for the rapid identification of mutated genes. Genetics 2005, 169:1779-1785.

21. Berezikov E, Bargmann Cl, Plasterk RHA: Homologous gene targeting in Caenorhabditis elegans by biolistic transformation. Nucl Acids Res 2004, 32:e40.

22. Till BJ, Reynolds SH, Greene EA, Codomo CA, Enns LC, Johnson JE, Burtner C, Odden AR, Young K, Taylor NE, Henikoff JG, Comai L, Henikoff S: Large-Scale Discovery of Induced Point Mutations With High-Throughput TILLING. Genome Res 2003, 13:524-530.

23. Greene EA, Codomo CA, Taylor NE, Henikoff JG, Till BJ, Reynolds SH, Enns LC, Burtner C, Johnson JE, Odden AR, Comai L, Henikoff S Spectrum of Chemically Induced Mutations From a LargeScale Reverse-Genetic Screen in Arabidopsis. Genetics 2003, 164:731-740.

24. Perry JA, Wang TL, Welham TJ, Gardner S, Pike JM, Yoshida S, Parniske M: A TILLING reverse genetics tool and a web-accessible collection of mutants of the legume Lotus japonicus. Plant Physiol 2003, | 3 |:866-87|.

25. Slade AJ, Fuerstenberg SI, Loeffler D, Steine MN, Facciotti D: A reverse genetic, nontransgenic approach to wheat crop improvement by TILLING. Nat Biotechnol 2005, 23:75-8I.

26. Smits BMG, Mudde J, Plasterk RHA, Cuppen E: Target-selected mutagenesis of the rat. Genomics 2004, 83:332-334.

27. Till BJ, Reynolds SH, Weil C, Springer N, Burtner C, Young K, Bowers E, Codomo CA, Enns LC, Odden AR, Greene EA, Comai L, Henikoff $\mathrm{S}$ : Discovery of induced point mutations in maize genes by TILLING. BMC Plant Biol 2004, 4: 12.

28. Wienholds E, van Eeden F, Kosters M, Mudde J, Plasterk RHA, Cuppen E: Efficient Target-Selected Mutagenesis in Zebrafish. Genome Res 2003, 13:2700-2707.

29. Winkler S, Schwabedissen A, Backasch D, Bokel C, Seidel C, Bonisch S, Furthauer M, Kuhrs A, Cobreros L, Brand M, Gonzalez-Gaitan M: Target-selected mutant screen by TILLING in Drosophila. Genome Res 2005, 15:718-723.

30. Anderson P: Mutagenesis. Caenorhabditis elegans: Modern Biological Analysis of an Organism 1995. none

31. Burns PA, Allen FL, Glickman BW: DNA sequence analysis of mutagenicity and site specificity of ethyl methanesulfonate in Uvr+ and UvrB- strains of Escherichia coli. Genetics 1986, I I3:8II-8I9.

32. Klungland A, Laake K, Hoff E, Seeberg E: Spectrum of mutations induced by methyl and ethyl methanesulfonate at the hprt locus of normal and tag expressing Chinese hamster fibroblasts. Carcinogenesis 1995, 16:128I-1285.

33. Kohalmi SE, Kunz BA: Role of neighbouring bases and assessment of strand specificity in ethylmethanesulphonate and $\mathrm{N}$ methyl-N'-nitro-N-nitrosoguanidine mutagenesis in the SUP4-o gene of Saccharomyces cerevisiae. I Mol Biol 1988, 204:561-568.

34. Pastink A, Heemskerk E, Nivard MJ, van Vliet CJ, Vogel EW: Mutational specificity of ethyl methanesulfonate in excisionrepair-proficient and -deficient strains of Drosophila melanogaster. Mol Gen Genet 199I, 229:2I3-2I8.

35. Rogalski TM, Gilchrist EJ, Mullen GP, Moerman DG: Mutations in the unc-52 gene responsible for body wall muscle defects in adult Caenorhabditis elegans are located in alternatively spliced exons. Genetics 1995, 139:159-169.

36. Oleykowski CA, Bronson Mullins CR, Godwin AK, Yeung AT: Mutation detection using a novel plant endonuclease. Nucl Acids Res 1998, 26:4597-4602.

37. Rosenbluth RE, Cuddeford C, Baillie DL: Mutagenesis in Caenorhabditis elegans : I. A rapid eukaryotic mutagen test system using the reciprocal translocation, eTI(III;V). Mutation Research/Fundamental and Molecular Mechanisms of Mutagenesis I983, I 1 0:39-48
38. De Stasio EA, Dorman S: Optimization of ENU mutagenesis of Caenorhabditis elegans. Mutat Res 200I, 495:8I-88.

39. CODDLE [http://www.proweb.org/coddle/]

40. Spieth J, Lawson D: Overview of gene structure (in press). WormBook 2005 [http://www.wormbook.org]. The C. elegans Research Community

4I. Konieczny A, Ausubel FM: A procedure for mapping Arabidopsis mutations using co-dominant ecotype-specific PCR-based markers. Plant J 1993, 4:403-4I0.

42. Taylor NE, Greene EA: PARSESNP: a tool for the analysis of nucleotide polymorphisms. Nucl Acids Res 2003, 31 I:3808-38I I.

43. Neff MM, Neff JD, Chory J, Pepper AE: dCAPS, a simple technique for the genetic analysis of single nucleotide polymorphisms: experimental applications in Arabidopsis thaliana genetics. Plant J 1998, I4:387-392.

44. Fraser AG, Kamath RS, Zipperlen P, Martinez-Campos M, Sohrmann $M$, Ahringer J: Functional genomic analysis of $C$. elegans chromosome I by systematic RNA interference. Nature 2000, 408:325-330.

45. Piano F, Schetter AJ, Mangone M, Stein L, Kemphues KJ: RNAi analysis of genes expressed in the ovary of Caenorhabditis elegans. Curr Biol 2000, 10:1619-1622.

46. Vatcher GP, Thacker CM, Kaletta T, Schnabel H, Schnabel R, Baillie $D L:$ Serine hydroxymethyltransferase is maternally essential in Caenorhabditis elegans. J Biol Chem 1998, 273:6066-6073.

47. Kitagawa R, Rose AM: Components of the spindle-assembly checkpoint are essential in Caenorhabditis elegans. Nat Cell Biol 1999, I:5|4-52|.

48. Park HK, Suh D, Hyun M, Koo HS, Ahn B: A DNA repair gene of Caenorhabditis elegans: a homolog of human XPF. DNA Repair (Amst) 2004, 3: I375-I383.

49. Sternberg PW, Han M: Genetics of RAS signaling in C. elegans. Trends Genet 1998, 14:466-472

50. Gilchrist EJ, Haughn GW: TILLING without a plough: a new method with applications for reverse genetics. Current Opinion in Plant Biology 2005, 8:2 I I-2I5.

51. Brenner S: The genetics of Caenorhabditis elegans. Genetics 1974, 77:7|-94

52. Colbert T, Till BJ, Tompa R, Reynolds S, Steine MN, Yeung AT, McCallum CM, Comai L, Henikoff S: High-Throughput Screening for Induced Point Mutations. Plant Physiol 200I, I 26:480-484.

53. Till B], Burtner C, Comai L, Henikoff S: Mismatch cleavage by single-strand specific nucleases. Nucl Acids Res 2004, 32:2632-264I.

54. Zerr T, Henikoff S: Automated band mapping in electrophoretic gel images using background information. Nucl Acids Res 2005, 33:2806-28I2.

55. Lieberman Research Worldwide [http://www.Irwonline.com/ stattest/index.htm]
Publish with Bio Med Central and every scientist can read your work free of charge

"BioMed Central will be the most significant development for disseminating the results of biomedical research in our lifetime. "

Sir Paul Nurse, Cancer Research UK

Your research papers will be:

- available free of charge to the entire biomedical community

- peer reviewed and published immediately upon acceptance

- cited in PubMed and archived on PubMed Central

- yours - you keep the copyright
BioMedcentral 